\title{
Fecundity of Metamysidopsis elongata (Crustacea: Mysidae) from Mazatlán Bay, Sinaloa, Mexico
}

\section{Fecundidad de Metamysidopsis elongata (Crustacea: Mysidae) de la Bahía de Mazatlán, Sinaloa, México}

\author{
Armando A. Ortega-Salas, Judith Nuñez, Sergio Rendón and Arturo Nuñez ${ }^{\dagger}$ \\ Instituto de Ciencias del Mar y Limnología y Posgrado, Universidad Nacional Autónoma de México. Calzada Joel M. Camarena s/n, Mazatlán, Sinaloa, 82040. México \\ e-mail: ortsal@cmarl.unam.mx
}

Recibido: 09 de noviembre de 2017. Aceptado: 28 de enero de 2018.

Ortega-Salas A. A., J. Nuñez, S. Rendón and A. Nuñez†. 2018. Fecundity of Metamysidopsis elongata (Crustacea: Mysidae) from Mazatlán Bay, Sinaloa, Mexico. Hidrobiológica 28 (1): 103-108. D0l: 10.24275/uam/izt/dcbs/hidro/2018v28n1/0rtega

\begin{abstract}
Background. In any culturing of organisms, to calculate fecundity we need to know how many descendants are produced. Goals. Marsupial and post-marsupial fecundity was calculated for Metamysidopsis elongata (Holmes, 1900) in two culturing generations (F1 and F2), and wild caught from Mazatlán Bay. Methods. From September 2010 to October 2011, we carried out monthly sampling on foot with a plankton net with a mesh size of $1000 \mu \mathrm{m}$ and a mouth opening of $50 \mathrm{~cm}$ in diameter. The fecundity evaluation was calculated with organisms fixed with formaldehyde at $4 \%$. Culturing occurred at a density of 5 ind $\cdot \mathrm{L}^{-1}$ at $22 \pm 1{ }^{\circ} \mathrm{C}$, salinity $32 \%$ with continuous aeration. The mysids were fed ad libitum with recently hatched Artemia nauplii. Results. The average marsupial fecundity was $6.28 \pm 2.94$ embryos per female in wild mysids, $4.51 \pm 1.20$ in the $F 1$, and $3.72 \pm 0.89$ in the F2. The average post-marsupial fecundity was $5.86 \pm 1.45$ in wild mysids, $3.74 \pm 1.20$ in the F1, and $3.32 \pm 1.42$ in the F2. No correlation between the length of females and fecundity was found. Conclusions. The fecundity of the wild mysids was present throughout the sampling cycle and was lower than that of the cultivated ones.
\end{abstract}

Keywords: culturing, fecundity, marsupial, Metamysipdopsis elongata, post-marsupial

\section{RESUMEN}

Antecedentes. En cualquier cultivo de organismos, el cálculo de la fecundidad es esencial para saber cuántos descendientes podríamos tener para planear nuestro trabajo. Objetivos. Se calculó la fecundidad marsupial y post-marsupial para Metamysidopsis elongata (Holmes, 1900) en dos generaciones de cultivo (F1 y F2) y silvestres capturados en la Bahía de Mazatlán. Métodos. Se realizaron muestreos mensuales a pie con una red de plancton de $1000 \mu \mathrm{m}$ de tamaño de malla con apertura de boca de $50 \mathrm{~cm}$ de diámetro entre septiembre de 2010 y octubre de 2011. La evaluación de la fecundidad se realizó con organismos fijados con formol al 4\% Los cultivos tuvieron una densidad de 5 ind $\cdot \mathrm{L}^{-1}$ a $22 \pm$ $1{ }^{\circ} \mathrm{C}$, salinidad $32 \%$ con aireación continua. Los mísidos fueron alimentados ad libitum con náuplios recién nacidos de Artemia. Resultados. La fecundidad marsupial media fue de $6.28 \pm 2.94$ embriones por hembra en mísidos silvestres, $4.51 \pm 1.20$ en el F1 y $3.72 \pm 0.89$ en el F2. La fecundidad post-marsupial media fue de $5.86 \pm 1.45$ en mísidos silvestres, $3.74 \pm 1.20$ en la F1 y $3.32 \pm 1.42$ en la F2. No hubo correlación entre la longitud de las hembras y la fecundidad. Conclusiones. La fecundidad de los mísidos silvestres estuvo presente a lo largo del ciclo muestreado y fue menor que la de los mísidos cultivados.

Palabras clave: cultivo, fecundidad, marsupial, Metamysipdopsis elongata, post-marsupial 


\section{INTRODUCTION}

Mysids species have a short reproductive cycle, which means they can quickly reproduce in vast numbers, and are a potentially useful food source for both wild and cultured organisms (Biju et al., 2009). In all species in the order Mysida, the females carry their embryos in the brood pouch or marsupium, a subthoracic chamber formed by pairs of overlapping oostegites, where juveniles develop until they attain the adult form (Price, 2004).

Metamysidopsis elongata (Holmes, 1900) has two currently recognized subspecies, the nominal subspecies $M$. e. elongata from the Pacific Ocean and M. e. atlantica (Băcescu, 1968) from the Atlantic Ocean (Băcescu, 1968).

Copulation, lasting a few seconds, occurs at night 2 or 3 minutes after the mature female has molted (Mauchline, 1980). Eggs are ejected from the external genital opening of the oviduct near the base of the sixth pair of pereiopods and the male sperm mass is placed in the pouch. The embryos (fertilized eggs) are incubated within the pouch until first larval ecdysis. The juveniles are released shortly thereafter, at night and over a short period of time, from minutes to an hour. After release, juveniles tend to sink and undergo a second larval ecdysis; statocysts appear and they are able to swim, acquiring their highly mobile juvenile form in a few minutes after release (Murano, 1999; and Mauchline, 1980).

Males and females develop distinct morphological features during the period of rapid growth before maturity (after maturity, growth becomes slower). In males, the four pleopods reach the trailing edge of the last abdominal segment, and the male lobe is fully developed and setose. Females have elongated oostegites (the marsupium growing) (Murano, 1999). However, Nair (1939) reported dimorphism in the first abdominal appendages and antennules, even though there is no development of the pouch and penis. After the release of juveniles, the female begins the molting cycle, copulation, embryos are developed, and release of juveniles again (Murano, 1999). The studies by Ortega-Salas et al. (2008) of the fecundity of Mysidopsis californica (W. M. Tattersall, 1932) from Mazatlán Bay under semi-controlled conditions showed a low correlation $(r=0.27, p=$ 0.196 ) between the number of released juveniles and female length. In addition, Rendon-Valdez (2013) studied some aspects of the reproductive biology of the mysid Amathimysis trigibba (Murano \& Chess, 1987) in natural conditions in Mazatlán Bay. Calil \& Borzone (2008) mentioned that tropical mysids, such as Metamysidopsis neritica (Bond-Buckup \& Tavares, 1992), reproduce continually in latitudes less than $40^{\circ} \mathrm{N}$. Ortega-Salas et al. (2015) studied growth and survival in $M$. elongate they grew. The average growth rates by the von Bertalanffy model for juvenile male and female mysids were $0.304 \mathrm{~mm}^{\text {day }}{ }^{-1}, 0.149 \mathrm{~mm}_{\text {day }}{ }^{-1}$ and $0.208 \mathrm{~mm}$ day $^{-1}$, respectively.

Fecundity is an important biological parameter because it indicates reproductive potential and is measured by the number of eggs, embryos, or larvae that females have in different sizes (Clutter \& Theilacker, 1971; Nath, 1973; Nuñez-Lecuanda, 2013). Also, data on fecundity are important in calculating the size of a stock, so the marsupial and postmarsupial fecundity of $M$. elongata in Mazatlán Bay was calculated under wild conditions and in two culture generations.

\section{MATERIALS AND METHODS}

On Mexico's Pacific coast in Mazatlán Bay, a surface sample of 250-300 mysids was collected manually each month from September 2010 to October 2011 over the sandy areas with a plankton net (mesh 1000 $\mu \mathrm{m}$, mouth opening $50 \mathrm{~cm}$ diameter). The water temperature and salinity were recorded for each sampling date and the organisms were transferred to the laboratory. Acclimation lasted three days. Transparent bottles $(4 \mathrm{~L})$ were used at a seawater temperature of $22 \pm 1^{\circ} \mathrm{C}$, salinity $32 \pm 1$, photoperiod 14:10 (light: dark) provided by $40 \mathrm{~W}$ fluorescent tubes and constant-soft aeration air-stones. Every day organisms were fed Artemia (aged 18-48 h and average length $480 \mu \mathrm{m}$ ) ad libitum; brand-INVE Aquaculture-Artemia Systems, grade A with a hatching rate of 100000 nauplii per gram dry cyst hatched under intense fluorescent light tube at $24{ }^{\circ} \mathrm{C}$ and salinity between 33 and 35 . Fifty percent of the water was replaced every two days. Males were distinguished by extended fourth pleopods, a lobe with hair-like setae, and the presence of antennae; females had elongated oostegites sufficient in size to form a pouch full size.

In 200 mysids of the wild population, marsupial stages of development were identified and described by Nuñez-Lecuanda (2013). Frequency of development stages determines the marsupial fecundity (number of embryos). A dilute menthol solution was applied to slowly numb their bodies, and after 10-15 minutes they were fixed with a solution of $4 \%$ formaldehyde for 5-10 minutes. The marsupial fecundity was determined by opening with a dissecting needle the pouch of each ovigerous female whose pouch showed no signs of damage. The terminology of Wortham-Neal and Price (2002) in Americamysis bahia (Molenock, 1969) was used for the description of embryonic stages. For the $\mathrm{F} 1$ and $\mathrm{F} 2$, the experimental design consisted of three $20 \mathrm{~L}$ aquaria with 100 newly released young mysids each (density of 5 ind $\cdot L^{-1}$ ).

The average and standard deviations of the data were processed with the Excel statistical package. Statistical analysis used StatSoftMR. Normality was tested (Kolmogorov-Smirnov with Lilliefors $p<0.05$ ) and then the nonparametric Kruskal-Wallis test was used.

To compare the proportions of ovigerous females and females with an empty pouch, a nonparametric Mann-Whitney U test was used. Significance was fixed at $p<0.05$. A correlation analysis between female length and number of embryos born was made.

\section{RESULTS}

In wild female mysids $(n=1400)$, the marsupium contained $6.28 \pm$ 2.94 embryos (range 1-18). Females with 4-7 embryos accounted for $55 \%$ of the population (Fig. 1, Table I). Average marsupial fecundity varied significantly with time $(H=259.5 ; p<0.05)$, being highest $(9.7$ $\pm 2.32)$ in September 2010 and lowest $(4.08 \pm 1.48)$ in August 2011 (Fig. 2). $86 \%$ of the females sampled had an average fecundity of 6.17 \pm 2.84 embryos. Of the F1 females, $83 \%$ were carrying 4-6 embryos, whereas of the F2 females $96 \%$ were carrying 3-5 embryos (Fig. 3).

Average marsupial fecundities of females F1 $(4.51 \pm 1.20)$ and F2 (3.72 \pm 0.89$)$ generations were significantly lower $(H=55.3 ; p<0.05$, Tukey's HSD) than in the wild females (avg. $6.28 \pm 2.94$ ), but they did not differ from each other. The wild females were significantly longer than those of the F1 and F2. Table II summarizes average fecundity 


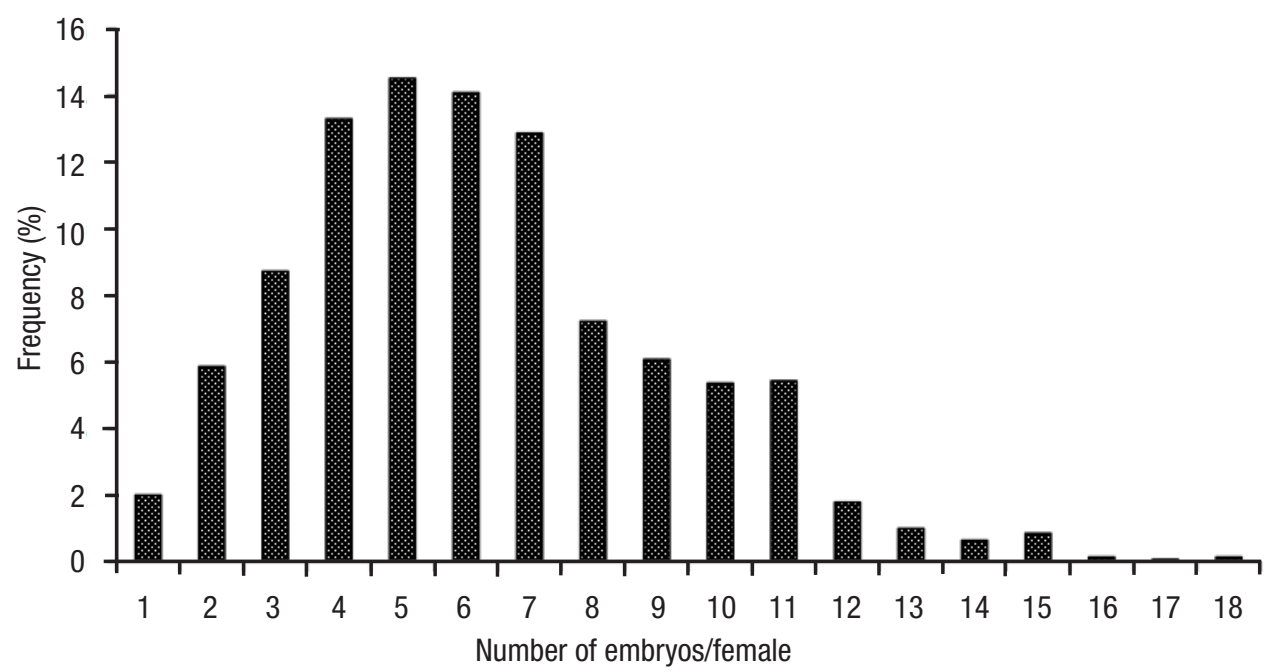

Figure 1. Frequency of fecundity in the marsupial sampling cycle of Metamysidopsis elongata (Holmes, 1900) from Mazatlán Bay, Sinaloa, Mexico.

ranges (SD) and the length (range, average, and SD) of wild, F1 and F2 females.

Average post-marsupial fecundity was $5.86 \pm 1.45$ in wild females $(n=95), 3.74 \pm 1.20$ in F1 females $(n=50)$, and $3.32 \pm 1.42$ in F2 females $(n=50)$ (Fig. 4).

The fecundity of wild post-marsupial mysids was significantly higher than that recorded in the cultures (Table 2, Fig. 4) (Nuñez-Lecuanda, 2013). The lengths of the wild, F1, and F2 females used in the evalua- tion of post-marsupial fecundity were not significantly different (ANOVA $\mathrm{F} 1,2,192=3.04, p>0.05)$. There was low correlation between fecundity and length in post-marsupial wild females $(r=0.05, p>0.05)$, and this also prevailed in F1 and F2 ( $r=0.33$ and $r=0.04, p>0.05$ in both cases). Within each generation there was a relationship between the number of embryos and the length of the female: In the wild females, the number of embryos increased at a rate of 1.10 embryos per $1 \mathrm{~mm}$ increase in female length; in the F1 this increase was 0.76 embryos, and in the F2 it was 0.61 .

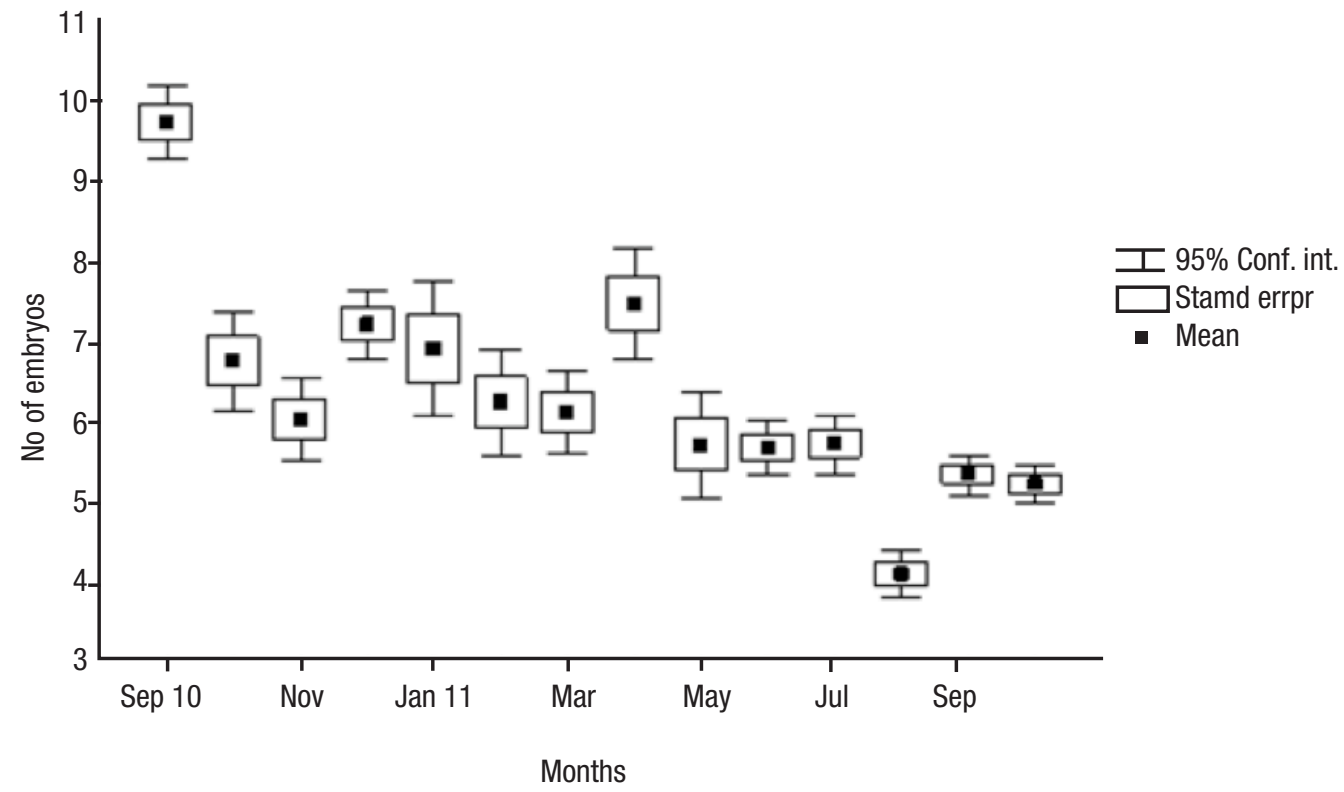

Figure 2. Marsupial fecundity of Metamysidopsis elongata (Holmes, 1900) during sampling cycle from Mazatlán Bay, Sinaloa, Mexico. 
Table 1. Embryo number (range, mean \pm , SD) in wild Metamysidopsis elongata (Holmes, 1900), and in cultured F1 and F2 at each development stage from Mazatlán Bay, Sinaloa, Mexico.

\begin{tabular}{|c|c|c|c|}
\hline & Wild & $\mathrm{F} 1$ & F2 \\
\hline Stage I & $\begin{array}{c}1-15 \\
(5.76 \pm 2.72) \\
(n=355)\end{array}$ & $\begin{array}{c}2-6 \\
(4.45 \pm 1.21) \\
(n=11)\end{array}$ & $\begin{array}{c}2-5 \\
(3.75 \pm 0.96) \\
(n=12)\end{array}$ \\
\hline Stage II & $\begin{array}{c}1-18 \\
(6.41 \pm 2.87) \\
(n=322)\end{array}$ & $\begin{array}{c}3-6 \\
(4.0 \pm 1.41) \\
(n=5)\end{array}$ & $\begin{array}{c}2-5 \\
(3.27 \pm 1.0) \\
(n=11)\end{array}$ \\
\hline Stage III & $\begin{array}{c}1-14 \\
(6.34 \pm 2.74) \\
(n=319)\end{array}$ & $\begin{array}{c}4-6 \\
(4.5 \pm 1.0) \\
(n=4)\end{array}$ & $\begin{array}{c}3-5 \\
(4.0 \pm 0.7) \\
(n=9)\end{array}$ \\
\hline Stage IV & $\begin{array}{c}1-16 \\
(6.31 \pm 3.18) \\
(n=420)\end{array}$ & $\begin{array}{c}3-7 \\
(4.81 \pm 1.25) \\
(n=11)\end{array}$ & $\begin{array}{c}3-5 \\
(3.91 \pm 0.79) \\
(n=12)\end{array}$ \\
\hline
\end{tabular}

\section{DISCUSSION}

Our observation of ovigerous females at 18-20 days was similar to the 25 days reported for M. e. atlantica (Gama et al., 2002) and (Gama et al., 2006).

Fecundity, an important part of reproductive potential, is measured by the number of eggs, embryos, and larvae with females at different sizes (Clutter \& Theilacker, 1971; Nath, 1973). In general, temperate mysids produce between two to three generations per year (Mees et al., 1994), whereas in the tropics they reproduce continuously (Goodbody, 1965). This was observed in M. elongata and Acanthomysis thailandica (Murano, 1986) as well as in other tropical organisms such as Mesopodopsis orientalis (W. Tattersall, 1908) (Hanamura, 2008; Biju et al., 2009; Biju \& Panampunnayil, 2010).
The temperature in the tropics where $M$. elongate is living is higher than other species and they reproduce continuously. During summer $\left(22^{\circ} \mathrm{C}\right)$, an average of $8.53 \pm 0.18$ embryos per female has been recorded for Mesopodopsis slabberi (Van Beneden, 1861), $42.65 \pm 1.43$ for Gastrosaccus spinifer (Goës, 1864), $16.04 \pm 0.06$ for Schistomysis kervillei (G. 0. Sars, 1885), and $6.09 \pm 0.35$ for S. spiritus (Norman, 1860 ), while in $M$. elongata the average marsupial fecundity was $6.28 \pm 2.94$ embryos per female in wild mysids, $4.51 \pm 1.20$ in the $F 1$ and $3.72 \pm 0.89$ in the F2. The average post-marsupial fecundity was $5.86 \pm 1.45$ in wild mysids, $3.74 \pm 1.20$ in the $F 1$, and $3.32 \pm 1.42$ in the F2 at temperature of $22 \pm 1{ }^{\circ} \mathrm{C}$, salinity $32 \pm 1$, photoperiod 14:10 (light: dark). The wild mísidos eat great variety of food, whereas the cultivated ones, only Artemia nauplii, this can be reflected in the number of offspring.

The relationship in $M$. elongate $(6-8 \mathrm{~mm})$ between the number of embryos and the lengths of wild progenitors females, F1, and F2 showed a rate of 1.10, F1 0.76, and F2 0.61 embryos for each unit of female length increase, respectively; these proportions were less than the ones found in in A. trigibba, a species of smaller size $(2.76 \mathrm{~mm})$ increase in length with 1.91 embryos / mm (Rendón-Valdez, 2013) and M. californica $(5.56 \mathrm{~mm})$ increase in length with 1.56 embryos / $\mathrm{mm}$ (Ortega-Salas et al., 2008). The giant mysid Gnathophausia ingens (Dohrn, 1870), the lophogastrid mysid (151 mm), has 1.0-2.31 embryos per $1 \mathrm{~mm}$ increase in the length of the female (Childress \& Price, 1978).

Mauchline (1980) stated that mysid fecundity is directly proportional to the total length of the females, and that it is an inverse function of the metabolic rate, which is directly proportional to the water temperature. In M. elongata from Mazatlán Bay, the number of embryos was low correlated with body length of females during the sampling cycle, whether in wild-caught females, or in the $\mathrm{F} 1$, or $\mathrm{F} 2(\mathrm{r}=0.04, \mathrm{r}=0.005$, and $r=0.04 ; p<0.05$, respectively). In $A$. thailandica, the maximum number of wild embryos recorded was 18 in a female of $5.51 \mathrm{~mm}$, but in other females the same size, minor and major size, the number of embryos in Stage I was 9, i.e., the same length females have different numbers of embryos (Ramarn, 2012).

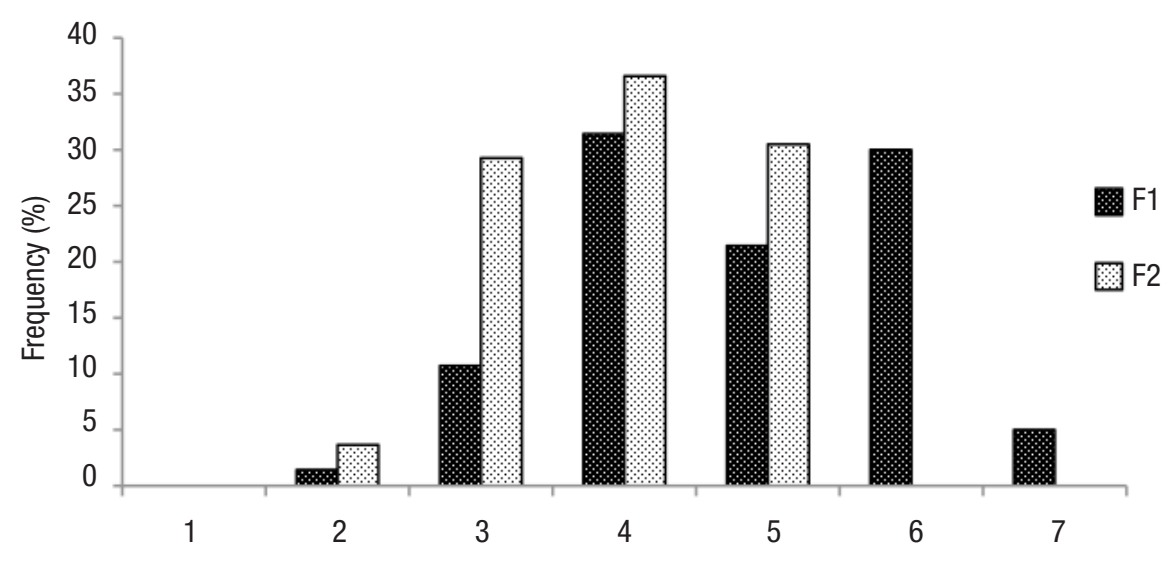

Number of embryos/female

Figure 3. Frequencies of marsupial fecundities among F1 and F2 females of Metamysidopsis elongata (Holmes, 1900) from Mazatlán Bay, Sinaloa, Mexico. 


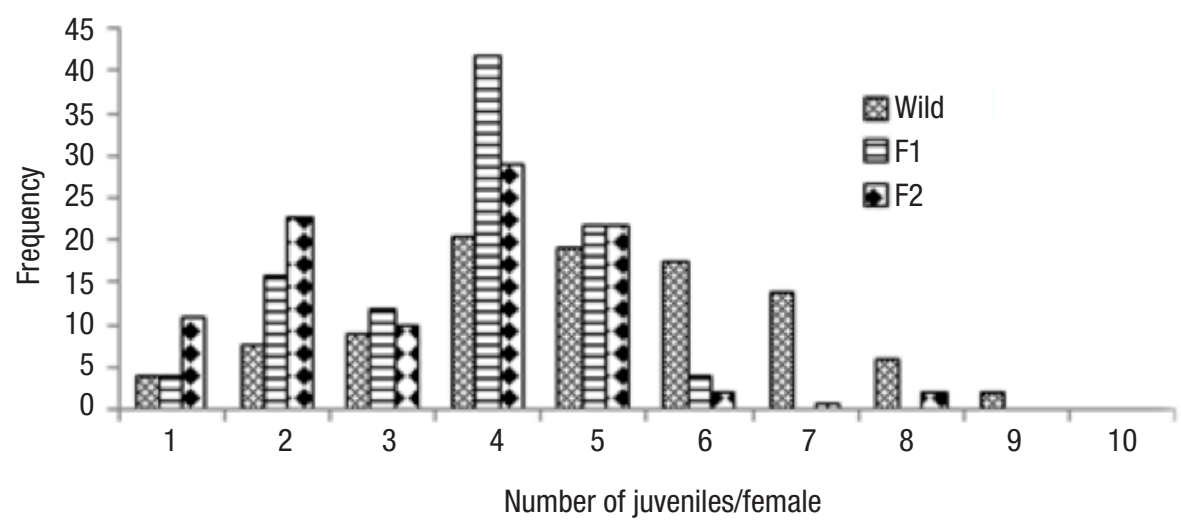

Figure 4. Frequencies of post-marsupial fecundities of wild, F1, and F2 females of Metamysidopsis elongata (Holmes, 1900) from Mazatlán Bay, Sinaloa, Mexico.

The fecundity of the wild mysids was present throughout the sampling cycle and was lower than that of the cultivated mysids.

Fecundity of Metamysidopsis elongate is essential for knowing how many descendants we could have to plan our work, but also to establish the marsupial and post-marsupial fecundity in the wild and in two culturing generations (F1 and F2). The continuous fecundity in the wild mysids was present throughout the sampling cycle, although it was lower in the cultivated ones; the ones in the wild ate a variety of organisms, while the cultivated ones ate just Artemia nauplii.

Table 2. Length (mm), marsupial and post-marsupial fecundity of Metamysidopsis elongata (Holmes, 1900) (interval, average, SD) of wild females, F1 and F2 from Mazatlán Bay, Sinaloa, Mexico.

\begin{tabular}{lccc}
\hline Marsupial & Wild & $\mathrm{F} 1$ & $\mathrm{~F} 2$ \\
\hline $\begin{array}{l}\text { Female length } \\
(\mathrm{mm})\end{array}$ & $4.24-6.98$ & $5.28-6.52$ & $5.36-6.62$ \\
& $(5.67 \pm 0.54)$ & $(5.95 \pm 0.42)$ & $(6.08 \pm 0.37)$ \\
Embryos number & $1-18$ & & \\
& $\begin{array}{c}(6.28 \pm 2.94) \\
(n=1400)\end{array}$ & $\begin{array}{c}(4.51 \pm 1.20) \\
(n=31)\end{array}$ & $\begin{array}{c}(3.72 \pm 0.89) \\
(n=44)\end{array}$ \\
& & & \\
& & & $2-5$ \\
Post-marsupial & $4.19-6.66$ & $4.43-6.53$ & $4.82-5.85$ \\
Female length & $(5.35 \pm 0.74)$ & $(5.41 \pm 0.60)$ & $(5.36 \pm 0.32)$ \\
(mm) & $(n=250)$ & $(n=50)$ & $(n=50$ \\
& & & \\
Juveniles released & $3-9$ & $1-6$ & $3-8$ \\
& $(5.86 \pm 1.45)$ & $(3.74 \pm 1.20)$ & $(3.32 \pm 1.42)$ \\
& $(n=95)$ & $(n=50)$ & $(n=50)$ \\
& & & $1.14-1.28$ \\
Juveniles length & $1.14-1.30$ & $1.14-29$ \\
(mm) & $(1.24 \pm 0.03)$ & $(1.20 \pm 0.03)$ & $(1.20 \pm 0.04)$ \\
& $(n=150)$ & $(n=150)$ & $(n=271)$ \\
\hline
\end{tabular}

\section{REFERENCES}

BăCEsCu, M. 1968. Etude des quelques Leptomysini (Crustacea Mysidacea) des eaux Du Bresil et de Cuba: description d'un genre et de cinq autres taxons nouveaux. Annali Museo Civico di Storia Naturale Genova 77: 232-249.

BiJu, A., R. Gireesh, K. J. Jayalakshmi, C. K. Haridevi \& S. U. Panampunnayll. 2009. Seasonal abundance, ecology, reproductive biology and biochemical composition of Mesopodopsis orientalis. W. M. Tattersall (Mysida) from a tropical estuary, Cochin backwater-India. Crustaceana 82: 981-996. DOI:10.1163/156854009X448835

Bisu, A. \& S. U. PanampunnaylL. 2010. Seasonality, reproductive biology and ecology of Mesopodopsis zeylanica Crustacea: Mysida) from a tropical estuary (Cochin backwater) in India. Plankton and Benthos Research 5: 49-55.

Calli, P. \& C. A. Borzone. 2008. Population structure and reproductive biology of Metamysidopsis neritica (Crustacea: Mysidacea) in a sand beach in south Brazil. Revista Brasileira de Zoologia 25 (3): 403-412. D0I:10.1590/S0101-81752008000300004

Childress, J. J. \& M. H. Price. 1978. Growth rate of the bathypelagic crustacean Gnathophausia ingens (Mysidacea: Lophogastridae). I. Dimensional growth and population structure. Marine Biology 50: 47-62.

Clutter, R. I. \& G. H. TheilaCker. 1971. Ecological Efficiency of a pelagic mysid shrimp; estimates from growth, energy budget and mortality studies. Fisheries Bulletin 69: 93-115.

Gama, A. M. S, M. A. Montu \& L. F. M. Gusmao. 2002. Ciclo de vida posmarsupial e crescimento de Metamysidopsis elongata atlántica (Crustacea, Mysidacea, Mysidae) em cultivo de laboratorio. Iheringia, Série Zoologia, Porto Alegre 92 (1): 77-83.

Gama, A. M. S, M. A. Montu \& F. D'Incao. 2006. Ciclo de mudas e taxas de crescimento de Metamysidopsis elongata atlántica (Crustacea: 
Mysidacea) cultivado em diferentes temperaturas e salinidades. Iheringia, Série Zoologia, Porto Alegre 96 (1): 67-70.

GoodBody, I. 1965. Continuous breeding in populations of two tropical crustaceans, Mysidium columbiae (Zimmer) and Emerita portoricensis Schmidt. Ecology 46: 195-197. DOI:10.2307/1935274

Hanamura, Y., R. Siow \& C. Phalk-Ean. 2008. Reproductive Biology and Seasonality of the Indo-Australasian mysid Mesopodopsis orientalis (Crustacea: Mysida) in a tropical mangrove estuary, Malaysia, Estuarine. Coastal and Shelf Science 77: 467-474.

Mauchline, J. 1980. The Biology of Mysids and Euphausiids. Advances in Marine Biology 18: 681.

Mees, J., Z. Abdulkerim \& 0. Hamerlynck. 1994. Life history, growth and production of Neomysis integer in the Westerschelde estuary (SW Netherlands). Marine Ecology Progress Series 109: 43-57.

Murano, M. 1999. Mysidacea. In: D. Boltovskoy (Ed). South Atlantic Zooplankton. Leiden, Backhuys Publishers. pp. 1099-1140.

NAIR, K. B. 1939. The reproduction, oogenesis and development of $\mathrm{Me-}$ sopodopsis orientalis Tatt. Proceedings of the Indian Academy of Sciences, Sect. B 9 4: 175-223.

NАTH, C. N. 1973. Breeding and fecundity in a subterranean mysid, Lepidomysis longipes (Pillai and Mariamma). International Journal of Speleology. 5: 319-323.

NeAL, J. L. \& W. W. Price. 2002. Marsupial developmental stages in Americamysis bahia (Mysida: Mysidae). Journal of Crustacean Biology 22: 98-112.

Nuñez-LeCuAndA, J. 2013. Evaluación de la fecundidad marsupial y posmarsupial de Metamysidopsis elongata (Holmes, 1900) (Crustacea:
Mysidae) en condiciones silvestres y semicontroladas de la costa de la Bahía de Mazatlán, Sinaloa México [Estimate of marsupial and post-marsupial fecundity of Metamysidopsis elongata (Holmes, 1900) (Crustacea: Mysidae) from the shore of the Mazatlán Bay, Sinaloa, México, under wild and semi-controlled conditions]. In: postgraduate thesis. 67 p. + figs. (Universidad Nacional Autónoma de Mexico, Mazatlan). Abstract available at http://132.248.246.25/ tesigrado/consulta/detpaterno.cfm?al_cuenta $=511014697$

Ortega-Salas, A. A., A. Núñez-Pastén \& H. A. Camacho. 2008. Fecundity of the crustracean Mysidopsis californica (Mysida, Mysidae) under semi-controlled conditions. Revista de Biología Tropical 56: 535539. D0I:10.6024/jmbai.2015.57.2.1866-15

Ortega-Salas, A. A., J. Nuñez-Lecuanda, S. Rendón R. \& A. Nuñez P. 2015. Growth and survival of Metamysidopsis elongata (Crustacea: Mysidae) from Mazatlán Bay, Sinaloa, Mexico. Journal of the Marine Biological Association of India 57 (2): 105-108. D0l:10.6024/jmbai.2015.57.2.1866-15

Ramarn, T., V. C. Chong \& Y. Hanamura. 2012. Population structure and reproduction of the mysid shrimp Acanthomysis thailandica (Crustacea: Mysidae) in a Tropical Mangrove Estuary, Malaysia, Zoological Studies 51: 768:782.

Rappe, K., N. Fockedey, C. V. Colen, A. Cattriusse, J. Mees \& M. Vincx. 2011. Spatial distribution and general population characteristics of mysids shrimps in the Westerschelde estuary (SW Netherlands). Estuarine, Coastal and Shelf Science 91: 187-197.

Rendón-VALdEZ, I. 2013. Algunos aspectos de la biología reproductiva de Amathimysis trigibba (Crustacea:Mysida). Tesis de Licenciatura. Facultad de Ciencias del Mar, Universidad Autónoma de Sinaloa. 